\title{
Die hermeneutiek van gereformeerde kerkreg
}

\begin{abstract}
Author:
Andries le Roux du Plooy ${ }^{1}$

Affiliations:

${ }^{1}$ School of Ecclesiastical studies, Potchefstroom Campus, North West

University, South Africa

Correspondence to:

Dries du Plooy

Email:

dries.duplooy@nwu.ac.za

Postal Address:

PO Box 20031, Noordbrug

2522, South Africa

Dates:

Received: 09 Sept. 2011

Accepted: 22 Nov. 2011

Published: 12 Oct. 2012

How to cite this article:

Le R du Plooy, A., 2012,

'Die hermeneutiek van gereformeerde kerkreg', In die Skriflig/In Luce Verbi 46(1), Art. \#36, 8 pages. http://dx.doi.org/10.4102/ ids.v46i1.36
\end{abstract}

(C) 2012. The Authors. Licensee: AOSIS OpenJournals. This work is licensed under the Creative Commons Attribution License.
Die artikel het op die belangrikheid en noodsaaklikheid van 'n hermeneutiek vir die gereformeerde kerkreg gefokus. Die kerkregtelike dokument wat besonderlik ter sake was, is die kerkorde van die Gereformeerde kerke in Suid-Afrika, met sy besondere band met die Dordtse kerkorde van 1618 en 1619. Agtereenvolgens is aandag gegee aan die volgende aspekte soos (1) die eiesoortige aard van 'n kerkorde as 'n teologiese dokument en teks, in onderskeiding van regsdokumente; (2) die aard van die hermeneutiek van kerkreg; (3) enkele teorieë oor die interpretasie of uitleg van tekste, veral regstekste en (4) normatiewe vooronderstellings en reëls vir die interpretasie en verstaan van die teks en artikels van die kerkorde asook besluite van kerklike vergaderinge. Die gevolgtrekking was dat weinig indringende navorsing gedoen is oor die saak van hermeneutiek vir kerkreg, hoewel dit noodsaaklik is. Duidelike hermeneutiese reëls is gesuggereer en verduidelik, wat sou kon meehelp dat kerke en kerklike vergaderinge die artikels van die kerkorde asook besluite en reglemente wat daarop berus het, kan interpreteer en toepas.

The hermeneutics of reformed church polity. The article focused on the importance and urgency of a design for reformed hermeneutics on church polity. The Church Order referred to in the article is the Church Order of the Reformed Churches in South Africa, which are closely related to the Church Order of Dordt of 1618 and 1619. The following aspects received attention namely (1) the unique character of a Church Order, in comparison to and distinguished from legal documents and statutes; (2) the character and nature of hermeneutics of church polity; (3) theories of interpretation in the common law tradition and their relevance to church polity and (4) normative presuppositions and marks for the interpretation and understanding of the text and articles of the Church Order, as well as the resolutions of church assemblies. It was found that minimum research has been done on the topic of hermeneutics for reformed church polity. This contribution was an effort to suggest and explain a number of hermeneutical principles and guidelines, which may serve and encourage churches and assemblies to interpret, utilise and apply the Church Order in an adequate and responsible way.

\section{Inleiding}

Hierdie artikel fokus op die belangrikheid en noodsaaklikheid van 'n hermeneutiek vir gereformeerde kerkreg. Hermeneutiek is 'n teoretiese dissipline wat hom besig hou met die bepaling en formulering van die beginsels en reëls wat ter sake en relevant is by die uitleg en verstaan van 'n geskrewe teks of dokument. Hermeneuse dui op die proses wat nodig is om ' $n$ teks te interpreteer en te verstaan (Coetzee 1995:1; Kuyper 1909:90 e.v.). In die teologie is daar tradisioneel sprake van hermeneutiek in die bibliologiese vakke, maar tog is daar ten opsigte van kerkreg as ' $n$ ekklesiologiese vak reeds ' $n$ besef dat ' $n$ kerkorde ' $n$ teks is wat korrek uitgelê en verstaan moet word (Van de Beek s.a.:59). Vandaar die titel van die artikel, naamlik Die hermeneutiek van gereformeerde kerkreg.

In hierdie bydrae wil ek ook my persoonlike dankbaarheid en erkentlikheid aan prof. J.M. (Koos) Vorster betoon, aan wie hierdie artikel opgedra word.

Dit is bekend dat hy in sy teologiese arbeid hoofsaaklik belangstelling in die gereformeerde etiek het, en besonderlik daaroor wetenskaplike bydraes gelewer het in die vorm van heelwat publikasies. Hy het egter ook teologiese bydraes op die terrein van die ekklesiologie gemaak, en veral in die vak Kerkreg. Hiervan is sy kommentaar op die kerkorde een voorbeeld (Vorster 1999).

Ten opsigte van die onderwerp wat ek in hierdie artikel aan die orde stel, gebruik ek graag ook 'n bydrae van hom, met die titel 'Kerkreg en konteks' (Vorster 1992:87-95), waarin hy byvoorbeeld 
stel: 'Verantwoorde kerkregering is slegs moontlik as gesonde hermeneutiese reëls in Kerkreg toegepas word. Oor hierdie reëls is nog baie besinning nodig' (Vorster 1992:91).

\section{Probleemstelling}

Binne die tradisie van gereformeerde kerke in die wêreld is die bestaan en funksionering van ' $n$ kerkorde ' $n$ algemene verskynsel en word dit as noodsaaklik geag omdat dit uit die Skrif duidelik blyk dat hoewel die Skrif nie kerkordelike bepalings bevat nie, God self wel in sy Woord die beginsels en basiese riglyne gegee het vir goeie en ordelike kerkregering. Daar is byvoorbeeld duidelike gegewens oor die ampte of dienste, oor die kerk, oor die doop en nagmaal en oor kerklike dissipline. Daarom is deeglike kerkregering deel van die gereformeerde belydenis (Du Plooy 1995:135-160; Smit 1985; Coertzen 1998).

In hierdie artikel lê die fokus nie soseer op die besondere verband tussen die Skrif, konfessie en kerkorde volgens die gereformeerde kerkreg nie, maar word dit as 'n gegewe aanvaar. In my eie intreerede het ek juis hierdie verband probeer aantoon en toelig op 'n prinsipiële en historiese wyse (vgl. Du Plooy 1988).

Die vraag is egter hoe lees en verstaan kerke en kerklike vergaderings die kerkorde oftewel kerkordelike bepalings. Is die artikels van die kerkorde slegs riglyne of is dit gesaghebbend? Wat is die effek daarvan dat dit van die 16de en 17de eeuse Reformasie dateer en dus moontlik uitgedien is; of dalk irrelevant is vir die kerk van die hede?

Omdat kerke in kerklike vergaderinge in die lig van die belydenis en 'n funksionerende kerkorde geregtig is om besluite te neem in belang van die kerke wat byvoorbeeld in ' $n$ meerdere vergadering (klassis, sinode) verteenwoordig word, kom die vraag telkens na vore watter kerkordelike bepaling(s) ter sake is, en hoe dit verstaan moet word. Verder word daar dan nie net ' $n$ besluit geneem ooreenkomstig die relevante riglyne en beginsels volgens die Skrif, konfessie en kerkorde nie, maar daar bestaan ook op hierdie wyse ' $n$ besluit of meer besluite wat op hulle beurt ook weer vir die regering en funksionering van die kerk belangrik is, en wat net soos die kerkordelike bepalings reg geïnterpreteer en toegepas moet word. Dit lei weer tot die vraag wat die verhouding is tussen kerklike sinodale besluite en kerkordelike bepalings. Voorbeelde hiervan is legio, maar ek volstaan met slegs ' $n$ aanduiding van die probleem:

- Die kerkorde van die Gereformeerde Kerke in Suid-Afrika (GKSA 1998) waarby ek my bepaal, en waarna ek telkens sal verwys, bevat 86 artikels oor wat as noodsaaklik vir die goeie en ordelike regering en funksionering van die kerke geag word. Die vraag is hoe ernstig moet dit gelees en toegepas word. Moet elke voorskrif of reël letterlik so toegepas word, of mag daarvan afgewyk word deurdat kerklike en/of meerdere vergaderinge so sou kon besluit?

- Mag kerke van besluite van sinodes afwyk deurdat dit nie uitgevoer word nie, sonder dat op 'n ordelike wyse daarteen beswaar gemaak is, in stryd met die reëling in artikels 31 en/ of 46 van die kerkorde van die GKSA?
- Hoe word die kerkorde as dokument in sy geheel asook ten opsigte van sy verskillende artikels gelees, verstaan en toegepas of moontlik geïgnoreer? Hiermee saam dan ook die vraag hoe die verband tussen besluite van kerklike vergaderinge en die artikels van die kerkorde verstaan behoort te word.

In die juridiese wetenskap het die belangstelling in die jongste tye geweldig toegeneem vir die studieveld van uitleg of interpretasie van wette, en tegelyk word van 'n positiwistiese en modernistiese benadering wegbeweeg asof die reg en regsreëls alles klinkklaar en helder is, en slegs so letterlik toegepas moet word (Nerhot 1990:193-225; Du Plessis 2001: para. 299-300; Van de Beek s.a.:59).

Dit het ook noodsaaklik geword dat kerke hulle vergewis van die gesag van kerklike bepalings en besluite, en dat seker gemaak word dat tekste in 'n kerkorde en besluite van kerklike vergaderinge suiwer en korrek geïnterpreteer moet word. Die hermeneutiek van die Woord van God bring mee dat die hermeneutiek van die kerkreg tot sy reg sal kom, juis vanweë die noue verband tussen die gesag van die Woord en die bepalings en besluite van kerklike vergaderinge.

\section{Doelstelling en uiteensetting}

Dit bring my by ' $\mathrm{n}$ formulering van die doelstelling van hierdie artikel, maar vooraf moet die opmerking gemaak word dat die artikel grotendeels bedoel om verkennend te wees. Dit sal my vreugde verskaf indien die oorsig wat gegee word, ook ander navorsers sal stimuleer om moontlik verder en dieper daaroor na te vors en te publiseer. Die lengte van 'n geakkrediteerde artikel asook die omvang van die saak verplig my om keuses te maak en te fokus op aspekte wat na my oordeel die mees relevante en aktuele waarde mag inhou.

Die doelstelling is om aan die hand van die volgende aspekte wat aan die orde gestel word, ' $n$ bydrae te probeer lewer sodat die kerkorde en ander kerklike besluite en prosedures wat op die kerkorde gegrond is of daaruit voortvloei, op 'n wetenskaplike en verantwoordelike wyse gelees, verstaan (geïnterpreteer) en aangewend word:

- Die eiesoortige aard van 'n kerkorde as dokument en as teks, veral ten opsigte van die teologiese aard daarvan in onderskeiding van regsdokumente soos 'n grondwet, statute of wette.

- Die aard van die hermeneutiek van kerkreg.

- Enkele teorieë oor die interpretasie of uitleg van tekste, veral tekste wat met die reg te maak het.

- Normatiewe vooronderstellings en reëls vir die interpretasie en verstaan van die teks en artikels van die kerkorde asook besluite van kerklike vergaderinge.

\section{Die kerkorde as dokument en as teks, en die onderskeiding tussen kerkreg en gewone reg}

'n Kerkorde is ' $n$ teologiese dokument wat kerklike sanksie geniet, en wat bedoel is om plaaslike kerke asook dié in kerklike verband of in ' $n$ kerklike eenheidsgemeenskap met 
mekaar te help om hul roeping as kerk in hierdie wêreld na te kom. ' $\mathrm{n}$ Ware kerk is in terme van die gereformeerde belydenis (Nederlandse geloofsbelydenis art. 29) te vind waar die merktekens aanwesig is, naamlik waar die Woord van God suiwer bedien en aangehoor word, waar die sakramente bedien word soos Christus dit ingestel het, en waar die dissipline of tug toegepas word ooreenkomstig die voorskrifte en vereistes van die Skrif. Die gereformeerde kerkorde is in die tyd van die Reformasie deur veral Bucer en Calvyn beskou as die gestaltegewing van hierdie drie komponente van ' $n$ ware kerk waarin juis die diens van die Woord, die sakramente en die kerklike tug of dissipline nader uitgewerk en geformuleer moet word, en wat tegelyk dien as die indeling van die kerkorde. Die doel hiervan is dat die kerk waarlik sy taak en roeping in die lewe van die kerk en in die wêreld kan vervul, sodat die kerk opgebou mag word, en goeie orde in die kerk onderhou kan word (Van 't Spijker 1972:35-37, 1993:192; Du Plooy 2008:246).

In Matteus 16:17-19 is sprake van die sleutels van die koninkryk van die hemel wat aan die kerk toevertrou word en waaruit blyk, saamgelees met Openbaring 3:7, dat die kerk geroep is om in die naam van Jesus Christus die kerk op te bou en te regeer. Die kerk het hiermee nie gesag naas Christus ontvang nie, maar die bevoegdheid (potestas) van Christus verkry wat volgens Calvyn (Inst. 4, 8, 1; Plomp 1969:63, 73) drieërlei van aard is: potestas doctrinae, potestas iurisdictionis, potestas in legibus ferendis (om te leer, te regeer en wette en/of bepalings te maak).

Die ontstaan en ontwikkeling van die teks van die kerkorde het in die 16de eeu tot vroeg in die 17de eeu plaasgevind, en het met die nasionale sinode van Dordrecht in Nederland in 1618 en 1619 sy beslag gekry. Hierdie ontwikkeling het parallel verloop met die leerstellige ontwikkeling van die gereformeerde belydenisskrifte. Die doctrina en die disciplina van die kerk het hand aan hand ontwikkel en is onlosmaaklik verbind aan mekaar (Van 't Spijker 1993:178-201; Nederlandse geloofsbelydenis art. 30-32). In die GKSA geld die Dordtse kerkorde van die begin in 1859 af, en is dit formeel in 1862 met die eerste sinode so aanvaar. In 1916 en 1964 was redelike indringende hersienings in die teks aangebring, en verder is daar van tyd tot tyd veranderinge van meer geringe aard aangebring, telkens sonder om die beginsels en inhoud materieel te verander, ooreenkomstig artikel 86 van die kerkorde. In die tydperk 1927-1930 is die kerkorde vanuit Nederlands in Afrikaans vertaal (Spoelstra 1966:40).

Die gesag van die kerkorde lê nie in homself nie, maar in sy verbondenheid aan die Skrif en belydenis. Die aard van die gesag is bedienend, en rus eintlik op twee ongelyke bene: eerstens op die Woord van God, en tweedens op die feit dat kerke in kerkverband onderling met mekaar ooreengekom het (mutuo consensu) om hulle te bind aan die artikels van die kerkorde ooreenkomstig artikels 31 en 86.

Na binne het die kerkorde sodoende bindende krag en word dit as die geldende reg beskou en onderhou. Dit is bekend as die ius constitutum.
Na buite dien die kerkorde as die interne verbandsreg van daardie kerkgemeenskap (Du Plooy 2008:248; Pienaar s.a.:17).

Ten opsigte van die hermeneutiek van kerkreg is dit daarom belangrik om in ag te neem dat die dokument waarmee ons werk, naamlik dat 'n kerkorde ' $n$ teologiese dokument is wat van toepassing is op die reg wat in die kerk geld en behoort te geld. Dit is bedoel om op die toepaslike gegewens van die Skrif te rus, altyd daaraan toetsbaar is en in alle gevalle die gees van die Skrif te adem. Dit het tot stand gekom onder leiding van die Woord en die Gees waarin kerke in samekomste gelei word om die wil van God soos Hy dit in sy Woord geopenbaar het, te soek, te orden en te formuleer.

Dit word onderskei van die gewone reg, van die wette wat onder leiding van die staat ooreenkomstig die grondwet van die land gemaak word. Van de Vyver (1994:178) handel insiggewend oor die onderskeid tussen kerk en staat, en toon aan hoe die kerk 'n eie interne gesag en reg het, wat hy nie van die staat ontleen het nie, maar wat voortspruit uit die kerk self as eiesoortige samelewingsverband.

Naas die verskille en onderskeiding tussen kerkreg en gewone reg is daar ook gemeenskaplikhede. Die gemeenskaplike aspek tussen wette in ' $n$ land ter wille van die handhawing van reg en orde en ' $n$ kerkorde is dat dit bedoel is om die reg te bepaal en om gehoorsaam en eerbiedig te word. Dit is daarom tekste wat juridies van aard is, wat voorskriftelik is, en wat vra om korrek geïnterpreteer te word. In hierdie geval kan die kerkreg heelwat leer by die gewone reg en by die navorsing wat gedoen word ten opsigte van die interpretasie van wette.

\section{Die aard van die hermeneutiek van kerkreg}

Van de Beek (s.a.: 61-62) verwys na Esser (1970:134-135) wat die aandag vestig op twee verskille wat juridiese tekste met historiese en literêre hermeneutiek het. Eerstens is die reg preskriptief van aard. Dit beskryf nie iets van die verlede (histories) of van die hede (literêr) nie, maar is imperatief van aard. Dit stel wat vereis word, wat die reg vir die huidige en vir die toekoms is.

Tweedens is die reg gerig op die huidige omstandighede. Dit stel wat tans geldig is, en behoort te wees. Die hermeneutiese spanningsveld wat so ontstaan, word veroorsaak deur die verband tussen die ontstaan van die teks of bepaling in die verlede en die vraag hoe en hoedanig dit in die huidige situasie behoort te geld.

In die geval van die kerkreg moet in gedagte gehou word dat 'n kerkorde vir 'n bepaalde gemeenskap bedoel is en ook deur daardie gemeenskap van gelowiges aanvaar is, waaraan hulle hulself gewillig onderwerp. Dit word deur niemand van buite of deur ' $n$ owerheid afgedwing nie omdat die kerk as gemeenskap van gelowiges hulle vrywillig en uit geloofsoortuiging by daardie geestelike en tog sigbare 
gemeenskap gevoeg het waar hulle in gehoorsaamheid aan die Hoof van die kerk, naamlik Christus wil lewe. Omdat die kerk so eiesoortig is, is die aard van die hermeneutiek van die kerkreg ook eiesoortig.

Net soos wat die reg egter bindend is vir die onderdane van 'n staat, so is die reg in die kerk kragtens die aard van die reg bindend teenoor elke lid(maat) van die kerk. Van de Beek (s.a.:62) stel dit duidelik dat 'n mens nie kan argumenteer dat aangesien die genade in die kerk moet heers, die reg ongeldig is nie. Reg is immers nie ongenadig of liefdeloos nie, maar eerder 'n vormgewing van God se liefde en genade. Wie die reg van God verbreek doen sonde, en die norm waarmee vasgestel word wat reg is, is in die Woord van God geopenbaar en is ook vanuit die Skrif in ' $n$ kerkorde geformuleer.

Omdat die kerk nie sy eie wetgewer is nie, en ook nie mag wees nie, aangesien die kerk die eiendom van Jesus Christus is en Hy die enigste Hoof van die kerk is, is die reg wat vanuit sy Woord en onder leiding van die Gees van God vasgestel is, gesaghebbend en bindend. Van de Beek (s.a.:62) wys tereg op 'n hermeneutiese vervlegtheid wat so ontstaan: die hermeneutiek van die Bybel, en die hermeneutiek van die kerkreg, waar die huidige geslag of die kerk van die hede binne ' $n$ eie konteks moet vasstel en interpreteer wat ou tekste presies vir vandag beteken, en hoe dit verstaan moet word.

Prakties beteken dit dat wanneer die aanspraak gemaak word dat 'n kerkorde met sy artikels direk en indirek op die Skrif berus (vgl. Nederlandse geloofsbelydenis art. 32), seker gemaak moet word dat die eksegese en hermeneuse van die Skrif suiwer en korrek gedoen is, en dat die formulering van ' $n$ artikel inderdaad ooreenkomstig die betrokke Skrifgedeelte(s) gedoen is.

Hiermee word nie beweer dat alle artikels direk uit die Skrif afgelei kan word nie, maar dit is wel waar dat wat in die kerkorde byvoorbeeld oor die dienste, oor die leer, oor die sakramente en tug geformuleer word, berus op eksegese en hermeneuse van die Skrif self. Dit is in die kerkreg as konstitutiewe bepalings bekend, naamlik as ius constitutum. Ook die ander artikels of bepalings in 'n kerkorde, die sogenaamde regulatiewe bepalings wat op grond van die ius permissivum (Nederlandse geloofsbelydenis art. 32) noodsaaklik geag word vir die goeie orde en reg in die kerke, is regsgeldig en bindend. Dit mag nie teen die Skrif indruis nie, maar moet die gees van die Skrif adem.

Wanneer by die hermeneutiek van kerkreg gekom word, behoort daar terdeë in ag geneem te word dat eksegese en hermeneuse van bepaalde Skriftekste gedoen is voordat die teks van die kerkorde geformuleer is. Net so ook ten opsigte van ander besluite of bepalings wat vir die goeie orde en regering van die kerk bedoel is (bv. prosedures of reglemente as toeligting en riglyne by die toepassing van sommige artikels van die kerkorde).

\section{Enkele teorieë oor die interpretasie of uitleg van tekste, besonderlik tekste wat met die reg te maak het}

Ten opsigte van 'n aantal teorieë van statutêre interpretasie meld Du Plessis (2001:par. 299) dat dit toenemend aktueel geword het, en besondere belangstelling in die juridiese wetenskappe geniet.

Daarom het daar ook ' $n$ aantal teorieë hieroor ontstaan waaraan ek kortliks aandag gee. Die bedoeling is om krities daaroor na te dink, en vas te stel wat vermy behoort te word of om te sien hoedanig dit diensbaar kan wees vir die hermeneutiek van kerkreg.

Ons fokus kortliks op die volgende: literalisme, intensionalisme, doelwit (purposivism) en kontekstualisme, regterlike aktivisme, objektivisme en postmodernisme.

\section{Literalisme}

Du Plessis (2001) skryf:

According to literalism in its crude, unqualified form, the meaning of a statuary provision can (and must) be retrieved from the ipsissima verba in which it is couched, regardless of manifestly unjust or even absurd consequences. (par. 302)

Literalisme oorbeklemtoon die letterlike of presiese woorde en gebruik van bepaalde woorde in ' $n$ wet of regsbepaling, en neem nie in ag dat woorde verskillende betekenisse en betekenisvelde kan hê nie.

In die kerkorde word woorde soos diens, amp en diensplig dikwels gebruik as vertaling van verskillende Latynse woorde, soos munus, officium, functio, ministerium. Die presiese betekenis en bedoeling in die Afrikaanse teks is nie altyd dadelik slegs eenduidig of beperk nie. So ook die gebruik van die woord tug en straf, om enkele voorbeelde te noem. Vergelyk verder by grammatiese interpretasie hieronder.

\section{Intensionalisme}

Steyn (1981:2), die eerste Suid-Afrikaanse regsgeleerde wat in 1940 meegehelp het dat ' $n$ dissipline soos die uitleg van wette in regskursusse gestalte gekry het, is van oortuiging dat die bedoeling of intensie van ' $n$ wet of bepaling die beslissende reël moet wees by die interpretasie van 'n wet. Kritici (vgl. Du Plessis 2001:par. 303) bevraagteken dit dat die intensie van 'n wet of wetgewing altyd so deursigtig en duidelik is, en aanleiding kan gee tot verskillende menings daaroor.

In die kerkreg is die intensie van 'n sinodale besluit dikwels nou verbind aan die historiese omstandighede en probleem wat toe aangespreek moes word, maar vir die huidige situasie is die intensie van die besluit - soos wat dit was toe dit geneem is - nie meer direk relevant nie. Tog kan die besluit nog relevant wees. Dit kan ook gebeur dat die intensie van 'n besluit nie presies vasgestel kan word nie en daar dus onduidelikheid bestaan daaroor. Dit maak dit derhalwe 
moeilik wanneer die intensie van 'n besluit deurslaggewend sou moes wees by die interpretasie daarvan. Vergelyk verder by teleologiese interpretasie hieronder.

\section{Doelwit en/of kontekstualisme}

Du Plessis (2001:par. 304) bespreek die teorie dat die interpretasie van wette bepaal sou word deur die doelwit wat met die bepaling of wet bereik wil word. Dit sluit aan by die teorie van intensionalisme en stem ooreen met die gedagte van kontekstualisme, asof die konteks die doelwit van die reël of wet bepaal.

Kritiek hierteen, volgens Du Plessis (2001:par. 304), is byvoorbeeld dat dit nie so maklik en duidelik is wat die eintlike doelwit en konteks was toe die wet of reël gemaak is nie. Net soos in die reg is die kerkreg ook daarop ingestel om orde en geregtigheid te dien, en om onreg of kwaad aan te spreek, elk op 'n eie wyse omdat daar 'n verskil is tussen die staatkundige en kerklike aard en omstandighede. Hoewel die historiese konteks en aanvanklike doelwit van 'n kerkordelike artikel of sinodale besluit belangrike inligting verskaf, sou dit moeilik beweer kon word dat die bepaling van die konteks deurslaggewend is vir die verstaan en toepassing daarvan. Watter norm of konteks buite die Skrif wat in kerklike sake die finale gesag dra, sou kon geld? Vergelyk verder by teleologiese interpretasie hieronder.

\section{Regterlike aktivisme}

Du Plessis (2001) bedoel met regterlike aktivisme die volgende:

In its moderate form, it recognises and justifies and, in its more radical form, strongly advocates judicial activism. It is premised on the belief that judges have a creative role to play in the interpretation an application of statute law. (par. 305)

Die kritiek hierteen is dat die interpretasie en toepassing van die reg - in die algemeen en in die kerk - sterk subjektiwisties word, kerklik neerkom op heerskappyvoering van een diens of van een kerk teenoor die ander (vgl. Kerkorde art. 17 \& 84). Oordele en beslissings berus dan eerder op subjektiewe keuses en oortuigings in plaas van op die korrekte interpretasie en toepassing van die relevante bepalings of besluite wat op grond van die Skrif vasgestel is.

Kerklik gebeur dit soms wanneer 'n meerdere vergadering sonder die opgaaf van redes, bloot op grond van aanvoeling en moontlik beïnvloeding deur partye in ' $n$ beswaarskrif of appèl, gemotiveerde aanbevelings van ' $n$ kommissie of deputate afwys.

\section{Objektiwisme}

Met objektivisme word bedoel dat die interpretasie van ' $n$ juridiese teks op sigself heeltemal duidelik is, en sonder enige subjektiewe wyse toegepas moet word (vgl. Du Plessis 2001:par. 306).

In die hermeneutiek van kerkreg is die bekende hermeneutiese reël dat ' $n$ bepaalde teks of artikel in ' $n$ bepaalde verband staan en dat een teks met ' $n$ ander vergelyk moet word, ook belangrik. 'n Kerkorde is een geheel, met afdelings en onderafdelings, maar in die interpretasie daarvan moet een bepaalde artikel se band en relevansie met ander artikels gesoek en verreken word en die doel van die kerkorde as geheel in ag geneem word. Dit bring mee dat, hoewel objektiwiteit belangrik is, aanvaar moet word dat objektiwisme asof een bepaalde besluit of artikel in ' $n$ kerkorde op sy eie genoegsaam duidelikheid vir die presiese verstaan daarvan bied, ' $n$ ekstreme standpunt is.

\section{Postmodernisme}

Du Plessis (2001) sê van postmodernisme:

Theoretical positions associable with the linguistic turn in legal interpretation represent a post-modern shift beyond prevailing common law positions, and question the conventional wisdom that legal interpretation characteristically involves the construction of generally applicable legal rules and/or norms and principles, followed by their application to the facts at hand. (par. 307)

En verder: 'meaning is not discovered in a text, but is made in dealing with the text.' Dit hang saam met die hermeneutiese en filosofiese ontwikkelinge in die literatuurwetenskap waarop ek nie ingaan nie. Die postmodernisme wys uit dat die vasstelling van een presiese uitleg nie so eenvoudig is nie, maar dat daar meer moontlikhede kan bestaan. Dit is so omdat taal en literatuur meer kompleks is. Tog beteken dit nie dat interpretasie aan die willekeur van die regter of in die geval van 'n kerk aan kerklike vergaderinge of kommissies uitgelewer is nie.

Hoewel die postmodernisme nie sonder kritiek is nie, het dit wel die oë geopen vir meer faktore wat in aanmerking geneem moet word by die verstaan en uitlê van tekste. Dit het ook die positiewe gevolg dat met groter verantwoordelikheid, krities omgegaan sal word met standpunte en interpretasies van tekste wat tradisioneel kritiekloos as die enigste ware interpretasie aanvaar word.

Samevattend blyk dit dat die verskillende teorieë wat bespreek is wel ' $n$ duidelike relevansie vir die hermeneutiek van kerkreg inhou. Daar is positiewe maar ook negatiewe elemente in elkeen aanwesig. Vir die kerkreg is dit van betekenis dat opnuut besin word oor hoe met die teks van ou dokumente soos ' $n$ reformatoriese kerkorde en ook met ou en nuwe besluite en reglemente wat in kerke geldig is, omgegaan word.

\section{Normatiewe vooronderstellings en reëls vir die interpretasie en verstaan van die teks en artikels van die kerkorde asook besluite van kerklike vergaderinge Geldigheid van die hermeneutiese reëls vir kerkreg}

Dit is belangrik dat vooraf gestel moet word dat die hermeneutiese reëls wat onderskei word, sal beantwoord 
aan die bedoeling van sulke reëls. Dit moet geldig as sleutels effektief wees by die proses van die interpretasie van 'n teks, soos ' $n$ besluit van ' $n$ kerklike vergadering asook veral by die uitleg van 'n artikel van die kerkorde. In die gewone regspleging word dit terdeë besef dat daar nie so maklik op een stel reëls vir die uitleg van wette gesteun kan word nie, omdat dit meerduidig en dikwels kompleks is (vgl. Dias 1970:147-148). Vir die kerkreg dien dit as aansporing om wel krities te kyk na die wyse waarvolgens te werk gegaan word om ' $n$ artikel van die kerkorde of ' $n$ besluit van ' $n$ meerdere vergadering nie net op grond van een geykte manier te verklaar nie. Dit sal hieronder verder uitgewerk word wat na ons oordeel moontlik in ag geneem behoort te word wanneer dit oor die vraag na die betekenis van 'n bepaalde artikel of sinodebesluit gaan.

\section{Vooronderstellings van hermeneutiek van kerkreg}

Vanuit 'n gereformeerde perspektief is dit 'n duidelike en uitgesproke vertrekpunt of vooronderstelling dat die Woord van God gesaghebbend is. Dit word bely in byvoorbeeld die Nederlandse geloofsbelydenis art. 2-7. Verder word dit aanvaar dat ' $n$ kerkorde se gesag op die Skrif berus en in sy bepalings die belydenis oor die kerk en die regering daarvan (Nederlandse geloofsbelydenis art. 27-32) vanuit die Skrifgewens in praktyk bring.

Die geldigheid van 'n kerkorde is daarom ' $n$ belangrike vertrekpunt by die uitleg van die kerkorde en besluite wat daarop gebasseer is. Die betrokke kerke in kerkverband het hulle vrywillig daartoe verbind om die kerkorde te aanvaar en toe te pas, sonder om daarmee te sê dat dit 'n afsonderlike regsdokument naas die Skrif is, asof dit op sigself kanoniek is. Die kerkorde sê immers van homself dat dit altyd toetsbaar aan die Skrif en belydenis is, en dat die artikels verander, vermeerder of verminder kan word, ooreenkomstig artikel 86 van die kerkorde (vgl. kerkorde art. 31 en 33; ook kredensiebrief by art. 33 van die kerkorde) (vgl. Coertzen 1998:60-67). Dit word verder veronderstel dat die kerke wie se kerkorde dit is, aanvaar dat dit normatief is, dat dit bedoel is vir die opbou van die kerk, dat dit die goeie orde in die kerke dien, en dat die artikels nie aanleiding gee tot onreg of onredelikheid of tot die deformasie van die kerke nie. En dat die aanvaarding van een gemeenskaplike kerkorde op grond van die onderlinge eenheid in Christus ook diensbaar is aan die handhawing en sigbare uitbouing van hierdie eenheid.

\section{Grammatiese interpretasie}

Du Plessis (2001:par. 336-344) bespreek die voor- en nadele van die grammatiese interpretasie, maar beklemtoon die belangrikheid daarvan dat die bepaalde teks waarmee gewerk word grammaties korrek gelees en verstaan moet word (vgl. Smith 2007:144-150).

Dit is ook van toepassing op die lees van kerklike tekste, byvoorbeeld kerklike besluite en kerkorde-artikels. Die grammatiese uitleg hou rekening daarmee dat die taalgebruik in genoemde dokumente of besluite bedoel is as gewone taal, en wanneer dit meer tegnies van aard is soos die verwysing na ' $n$ sinode of kuratore, dan word aanvaar dat daar in die sfeer van die kerklike lewe nie vreemde of onbekende woorde en uitdrukkings is nie.

Dit is wel noodsaaklik dat rekening gehou word met die feit dat sommige woorde of uitdrukkings argaïsmes kan wees of so verouderd dat die betekenis daarvan nie meer so duidelik vir die hedendaagse leser is nie.

Die suggestie kan gemaak word dat oorweging geskenk sal word aan die taalgebruik in die kerkorde sodat argaïsmes verwyder sal word, net soos die kerkorde in die jare 1927-1930 vanuit Neerlands vertaal is, en daarna voortgegaan is om die Nederlandismes wat oorgebly het te vervang met Afrikaanse woorde. Verder sou ' $n$ formele woordomskrywing of eenvoudige definisie as ' $n$ bylaag tot die kerkorde bygevoeg kon word ten einde duidelikheid te gee oor die betekenis van bepaalde voorkomende woorde en begrippe in die kerkorde.

\section{Sistematiese interpretasie - ook bekend as kontekstuele of strukturele interpretasie}

Du Toit (1992:17) verwoord die feit dat, ten opsigte van die regshermeneutiek, die pendulum vinnig wegbeweeg van 'n letterlike (meer grammatiese) verstaan van tekste na 'n duidelike kontekstuele benadering. Ook Smith (2007: 144-145) wys daarop dat hoewel daar in die tyd van die Verligting gewaarsku is dat te veel interpretasie maklik kon lei tot vervalsing van die teks en dat liefs noukeurige wette en bepalings gemaak moes word wat weinig interpretasie verg, dit nie uit die oog verloor moet word dat die konteks wel 'n besondere rol speel nie.

Du Plessis (2001:par. 345) sê: 'Systematic interpretation reveals the (logical or systematic) scheme of the text.' Dit is kontekstualisties van aard omdat ' $n$ bepaalde teks in die konteks van 'n geheel verstaan moet word. Dit is deel van ' $n$ sisteem of 'n logiese geheel.

Hierdie sisteem of geheel verwys nie net na die hele dokument soos ' $n$ kerkorde nie, maar ook en eintlik na die hele tradisie en etos en konfessionele paradigma waarbinne die bepaalde kerkverband staan. Dit beteken dat die bepaalde belydenisskrifte soos die Drie Formuliere van Eenheid bepalend is vir die sisteem waarbinne die kerkorde ontstaan het en steeds bestaan. Dit speel ' $n$ kardinale rol by die uitleg van die artikels van die kerkorde.

Hierdie kontekstuele benadering hou verder in dat daar benewens ' $n$ intra-tekstuele aspek ook ' $n$ inter-tekstuele aspek is.

Met intra-tekstueel word bedoel dat net soos in die Bybelse hermeneutiek Skrif met Skrif, oftewel reël met reël, vergelyk moet word. 'n Bepaalde artikel van die kerkorde moet in sy verband met ander artikels, asook in verband met die geheel van die kerkorde, gelees en verstaan word. Die struktuur van die kerkorde wat getuig van 'n bepaalde wyse van ontwerp 
en logika, is daarom baie relevant en betrokke by die hermeneutiek van die kerkreg. Om hierdie rede praat Van de Beek (s.a.:63) van strukturele hermeneutiek.

Met inter-tekstueel word bedoel dat daar ' $n$ verband of ooreenkoms met ander soortgelyke tekste bestaan. In die geval van kerkreg is daar ook ander kerkordes binne ander gereformeerde of selfs nie-gereformeerde kerke waarvan kennis geneem behoort te word, en gelet te word op die formulering en bedoeling daarvan. Ons sou hier ook van komparatiewe hermeneutiek (vgl. Du Plessis 2001:par. 363) kon praat. Beklemtoon dat by die uitleg en toepassing van die artikels van die kerkorde rekening gehou moet word met die ekumenisiteit van die kerk, besonderlik met die kerke waarmee daar kerklike korrespondensie (vgl. kerkorde art. 52) of ekumeniese eenheid bestaan.

Hierby moet verder verwys word na die konteks van die tyd en omstandighede waarin die oorspronklike teks geskryf is, asook na die konteks waarin dit deur die geskiedenis gelees en verstaan is. Daarby ook die huidige konteks waar dit nou van toepassing gemaak moet word.

Vorster (1992:87-95) handel oor die relevansie van die konteks ten opsigte van die hermeneutiek van kerkreg en wys op die feit dat die konteks as sodanig nie die inhoud bepaal nie, maar wel in ag geneem moet word. Die konteks wat in ag geneem word vrywaar die kerk van absolutisme enersyds en aan die ander kant moet toegesien word dat konteks nie lei tot relativisme nie asof die kerkreg nie beginsels vir die kerkregering bied nie. Vorster maan tereg dat absolutisme tydgebonde ordereëlings tot beginsels wil verhef en dat relativisme beginsels ontken en alles wil laat bepaal deur die praktyk.

\section{Teleologiese interpretasie}

Die teleologiese benadering in die hermeneutiek van die kerkreg beteken dat ernstig gepoog word om die bedoeling van die reg in die kerk, soos geformuleer en vergestalt in die kerkorde, te laat realiseer.

Dit is daarom 'n uiters belangrike hermeneutiese reël waarmee gewerk moet word, en is bedoel en gerig op die vasstelling en toepassing van die wil van God sodat sy reg sal geskied. Die kerkorde wil juis hieraan diensbaar wees in sy bedoeling en uiteensetting.

Van de Beek (s.a.:64) beklemtoon dat die kerkreg se doel juis daarin verwesenlik word wanneer God se reg geskied het. Indien dit sou beteken dat ' $n$ betrokke besluit van ' $n$ kerklike vergadering of selfs ' $n$ artikel van die kerkorde om daardie rede gewysig moet word, dan moet dit gebeur omdat die Woord van God deurslaggewend is en alle ander bepalings en besluite daaraan toetsbaar is.

Smith (2007:164) wys daarop dat 'n beroep op die bedoeling en strekking van ' $n$ bepaling nie net verwys na die bedoeling wat die opstellers van die betrokke reël gehad het by die aanvanklike formulering daarvan nie, maar ook op die bedoeling en strekking wat dit in die huidige konkrete situasie kan hê. In hierdie verband kom die teleologiese en die kontekstuele aspekte naby mekaar.

\section{Historiese interpretasie}

Du Plessis (2001:par. 357) meen tereg dat 'n teleologiese interpretasie sonder ' $n$ historiese fondament leeg is. Die geskiedenis van ' $n$ bepaalde wet of reël vertel baie van die sogenaamde ratio legis, volgens Von Savigny (aangehaal deur Du Plessis 2001:par. 357).

Historiese hermeneutiek vra na die historiese konteks waarbinne die regsreël ontstaan het. Van de Beek (s.a.:63) onderskei drie aspekte ten opsigte van historiese hermeneutiek:

- Wetshistories: Hiermee word bedoel dat vasgestel moet word wat die betrokke reël of bepaling, regspositief gesien, in sy oorspronklike formulering beteken het.

- Regshistories: Teen watter geskiedenis in terme van die tydsgees en omstandighede en diskoerse het die bepaling ontstaan? Die kerkorde waarmee ons opereer, het juis teen die agtergrond van die Reformasie in 'n anti-Roomse (teenoor die episkopalisme) en anti-anabaptistiese tyd ontstaan en dit moet verreken word by die uitleg van die artikels.

- Die geskiedenis van die funksionering: Hoe is die bepaling in die verlede toegepas en hoe is die woorde en begrippe in die verlede verstaan en gebruik? Waarop was dit van toepassing?

\section{Rasionaliteit, legaliteit en legitimiteit}

Die kerkorde as dokument verwoord die reg en orde wat in, en ter wille van die kerke in die bepaalde kerkverband bedien moet word, wat rasioneel aan die vereistes van reg en orde tot opbou van die kerke beantwoord, wat legaliteit (regsgeldigheid) en legimiteit (geoorloofdheid, geregverdigheid) besit omdat dit op die Skrif berus, en omdat dit met algemene, onderlinge ooreenstemming aanvaar is (mutuo consensu vgl. art. 86; vgl. Van de Beek s.a.:66-68).

Daarom geniet die kerkorde normatiewe status en word dit saam met en in die lig van die Skrif byvoorbeeld gebruik om, wanneer nodig kerklike sake en kerklike besluite ook aan die kerkorde te toets, en om aangewend te word in geval van regspraak en van tug (vgl. art. 31 kerkorde). Dit besit dus regsgeldigheid of legaliteit.

Die kerkorde het nie en pretendeer nie om selfstandige gesag naas die Skrif te hê nie. Omdat dit die produk is van kerke - al het dit tot stand gekom onder leiding van die Woord en Gees - is dit nie volmaak nie, maar feilbaar. Dit word duidelik verreken in artikel 86, ooreenkomstig die beginsel van artikel 32 van die Nederlandse geloofsbelydenis.

Dit kan en moet gebeur dat kerke en kerklike vergaderinge op 'n ordelike wyse, soos wat die kerkorde self reël, krities 
navors en besin oor die vraag of die opbou en welsyn van die kerke nie vereis dat veranderings, vermeerderings of verminderings aan die kerkorde aangebring moet word nie. Die legimiteit of die geregverdigheid van die artikels, asook die relevansie en redelikheid van die kerkorde moet rasioneel in die lig van veranderde en veranderende omstandighede, in die lig van die Woord en onder leiding van die Gees beoordeel en getoets word.

\section{Slotopmerkings}

Die navorsing oor die hermeneutiek van kerkreg het aangetoon dat daar waarskynlik ' $n$ leemte, oor die onderwerp bestaan omdat daar nog nie omvattend en sistematies hieroor geskryf is nie. In die regswetenskap is uitvoerig hieroor gepubliseer en heelwat van wat oor die regshermeneutiek geskryf word, is van besondere waarde en betekenis vir die hermeneutiek van kerkreg.

My bedoeling was om met hierdie verkennende uiteensetting na my oordeel grondliggende aspekte uit te lig en die belangrikheid en relevansie daarvan te verduidelik. ' $n$ Volgende bydrae oor die onderwerp sou hierop kon voortbou, en moontlik krities kon fokus op hoe die kerkorde wel in die praktyk van die kerklike lewe en in kerklike vergaderinge gebruik en geïnterpreteer word.

Dit is my oortuiging dat dit van besondere belang is dat kerke en kerklike vergaderinge wat in die praktyk van die kerklike lewe daarmee werk ter wille van die opbou en die bediening van die kerke, ernstig sal kennis neem van die belang van 'n saak soos die hermeneutiek van kerkreg.

\section{Erkenning \\ Mededingende belang}

Die outeur verklaar dat hy geen finansiële of persoonlike verbintenis het met enige party wat hom nadelig kon beïnvloed in die skryf van hierdie artikel nie.

\section{Literatuurverwysings}

Coertzen, P., 1998, Church and order: A Reformed Perspective, Peeters, Leuven.

Coetzee, J.C., 1995, Hermeneutics and exegesis of the New Testament: Pt 1 Hermeneutical Rules, Wesvalia, Potchefstroom.

Dias, R.W.M., 1970, Jurisprudence, 3rd edn., Butterworths, London.

Du Plessis, L.M., 2001, 'Statute law and interpretation', in W.A. Joubert \& J.A. Faris (eds.), The law of South Africa First Reissue, vol. 25, Pt 1, pp. 223-413, pars. 278365, Butterworths, Durban.

Du Plooy, A. Le R., 1988, Die verband tussen die Skrif, konfessie en kerkorde volgens die gereformeerde kerkreg, $\mathrm{PU}$ vir $\mathrm{CHO}$, Potchefstroom.

Du Plooy, A. Le R., 1995, 'Die grondslag en relevansie van die gereformeerde kerkreg as teologiese wetenskap', In die Skrflig 29(1/2), 135-160.

Du Plooy, A. Le R., 2008, 'Kerkorde en grondwet - in die lig van God se koninkryk', Nederduitse Gereformeerde Teologiese Tydskrif 49(1/2), 243-252.

Du Toit, D.C., 1992, 'The problem of the "correct interpretation" in law, Freedom and humanism in interpretation' [Die probleem van die 'korrekte interpretasie' in die wet, Vryheid en humanisme in interpretasie], Tydskrif vir Regswetenskap 17(2), $15-28$.

Esser, J., 1970, Vorverständnis und Methodenwahl in der Rechtsfindung: Rationalitätsgarantien der richterlichen Entsheidungspraxis, Athenäum Taschenburg Fischer Verlag, Frankfurt am Main. (Entscheidungspraxis [Studien und Texte zur Theorie und Methodologie des Rechts]).

Kerkordeboekie van die Gereformeerde Kerke in Suid-Afrika, 1998, Administratiewe Buro van die GKSA, Potchefstroom.

Kuyper, A., 1909, Encyclopaedie der heilige Godgeleerdheid, Pt. 3, 2de hersiende uitg., Kok, Kampen.

Nerhot, P., 1990, 'Interpretation in Legal Science', in P. Nerhot (ed.), Law, interpretation and reality, pp. 193-225, Kluwer, Dordrecht. (Essays in Epistemology, Hermeneutics and Jurisprudence vol. 11).

Pienaar, G.J., s.a., Die regsposisie van die Gereformeerde Kerke in Suid-Afrika, EFJS, Potchefstroom.

Plomp, J., 1969, De kerklijke tucht bij Calvijn, Kok, Kampen.

Smit, C.J., 1985, 'Kerkreg en kerkorde in die lig van God se reg en orde vir sy kerk', Th.D proefskrif, Fakulteit Teologie, PU vir CHO, Potchefstroom.

Smith, C.E., 2007, Regels van rechtsvinding, Tweede herziene druk, Boom Juridische uitgewers, Den Haag.

Spoelstra, B., 1966, 'Inleiding', in L.S. Kruger, B. Spoelstra, T. Spoelstra, T. \& H.L.M. Du Plessis (reds.), Handleiding by die kerkorde van die Gereformeerde Kerk in SuidAfrika, pp. 11-41, Pro Rege, Potchefstroom.

Steyn, L.C., 1981, Die Uitleg van Wette, 5 de uitg., Juta, Kaapstad.

Van de Beek, A., s.a. 'Hermeneutiek van de kerkrecht', in W. Van't Spijker \& L.C. Van Drimmelen (reds.), Inleiding tot de studie van het kerkrecht, pp. 59-72, Kok, Kampen.

Van de Vyver, J.D., 1994, 'Religion' [Godsdiens], LAWSA 23, 175-202.

Van 't Spijker, W., 1972, Goddelijk recht en kerkelijke orde bij Martin Bucer, Kok, Kampen.

Van 't Spijker, W., 1993, 'Reformatie en kerkorde', Theologia Reformata 36(3), 178 201

Vorster, J.M., 1992, 'Kerkreg en konteks', Studia Historia Ecclesiastica XVIII(1), 87-95.

Vorster, J.M., 1999, An introduction to Reformed Church Polity, Potchefstroom Teologiese Publikasies, Potchefstroom. 